\title{
HUBUNGAN TINGKAT PENGETAHUAN IBU TERHADAP DETEKSI DINI KANKER PAYUDARA DAN PERILAKU SADARI DESA TUMPAAN BARU MINAHASA SELATAN
}

\author{
Meike Sandepa ${ }^{1}$, Wahyuny Langelo ${ }^{2}$ \\ Program Studi Ilmu Keperawatan ${ }^{1,2}$ \\ Universitas Katolik De La Salle Manado ${ }^{1,2}$ \\ e-mail:11061079@unikadelasalle.ac.id ${ }^{1}$; wlangelo@unikadelasalle.ac.id ${ }^{3}$
}

\begin{abstract}
Cancer is one of primary causes of death in all around the world. In North Sulawesi, there were an estimated 346 cases in 2013. One of the early detection program which easy to do is BSE. BSE is a screening tool that can get the breast cancer in early stage. Breast cancer is common disease affecting women in age more than 40, but in fact the mothers has not do the BSE regularly. Aim of the study to determine the knowledge of breast cancer early detection and BSE practice among mothers. This study was to investigate the relationship between the knowledge of breast cancer early detection and BSE practice. A cross-sectional study with descriptive analyze. The study comprised 55 mothers of ages 3060 years, sampled by purposive sampling. Data was collected by a voluntary self-administrated questionnaire. Among respondents 63,6\% who reported had high educational as the latest education. The knowledge about breast cancer early detection among the respondents $92,7 \%$ were in good category, $74,5 \%$ were practice BSE, and 72,7\% were in good category of knowledge who practice BSE. These findings investigate the knowledge of breast cancer early detection has a meaningful relationship with BSE practice among mothers in Tumpaan Baru.
\end{abstract}

Keywords: $\quad$ Knowledge, Practice, Breast Cancer Early Detection, Breast-Self Examination, Mother

\section{A. PENDAHULUAN}

Kanker payudara merupakan pertumbuhan sel payudara yang tidak terkontrol karena terjadi perubahan abnormal dari gen yang berperan dalam pembelahan sel. Penyakit kanker merupakan salah satu penyebab kematian utama di seluruh dunia. Pada tahun 2012, sekitar 8,2 juta kematian disebabkan oleh kanker. Kanker paru, hati, perut, kolorektal, dan kanker payudara adalah penyebab terbesar kematian akibat kanker setiap tahunnya. World Health Organization (WHO) berpendapat bahwa kanker adalah penyebab utama kematian dan mengakibatkan 7,6 juta kematian pada tahun 2008 di dunia (GHO 2015).

Berdasarkan data The International Agency for Research in Cancer melalui
Globocan (Global Burden of Cancer) tahun 2012 diketahui bahwa kanker payudara merupakan penyakit kanker dengan persentase kasus baru (setelah dikontrol oleh umur) tertinggi, yaitu sebesar $43,3 \%$, dan persentase kematian (setelah dikontrol oleh umur) akibat kanker payudara sebesar $12,9 \%$. WHO memperkirakan pada tahun 2012, 13\% kematian yang terjadi di Indonesia terjadi diakbitkan oleh kanker. Kematian akibat kanker payudara sebesar 21,4\% di Indonesia tahun 2014. Pada tahun yang sama angka kejadian kanker payudara di Indonesia sebanyak 48,998 kasus (WHO 2014). Menurut pusat data dan informasi Kementerian Kesehatan RI, pada tahun 2013 estimasi jumlah absolut penderita kanker payudara di Provinsi Sulawesi Utara sebanyak 346 orang. 
Keluarga merupakan unit sosial penting dalam bangunan masyarakat (Lestari 2012). Seseorang melakukan adaptasi dimulai dari keluarga sebelum ia masuk ke dalam kelompok sosial yang lebih besar. Dalam proses tersebut, dibutuhkan sosok seorang ibu. Ibu dalam keluarga memiliki peran yang penting yaitu untuk memenuhi kebutuhan fisiologis dan psikis anggota keluarganya, merawat dan mengurus keluarga dengan sabar, mesra dan konsisten, sebagai pendidik yang mampu mengatur dan mengendalikan anak, sebagai contoh dan teladan, sebagai manajer yang bijaksana, memberi rangsangan dan pelajaran, dan sebagai istri (Gunarsa 2008). Namun, ibu dengan segala tugas dan peran yang dijalaninya mereka melupakan bahwa mereka adalah seorang wanita yang memiliki kemungkinan untuk menderita kanker payudara sama halnya dengan semua wanita di dunia. Ditambah lagi 95\% dari kasus baru dan 97\% kematian akibat kanker payudara terjadi pada wanita usia 40 tahun ke atas (American Cancer Society, 2012).

Kanker yang diketahui sejak dini memiliki kemungkinan untuk mendapatkan penanganan lebih baik (Pusat Data dan Informasi Kementerian Kesehatan, 2015). Gaya hidup seperti perilaku yang perlu diubah yaitu membiasakan diri dengan deteksi dini kanker payudara. Salah satu cara deteksi dini yang mudah untuk dilakukan yaitu pemeriksaan payudara sendiri (SADARI). SADARI merupakan usaha untuk mendapatkan kanker payudara pada stadium yang lebih dini (Manuaba 2010). Ternyata 75-85\% keganasan kanker payudara ditemukan pada saat dilakukan pemeriksaan payudara sendiri (Purwoastuti 2008).

Data yang diperoleh dari puskesmas Tumpaan Minahasa Selatan terdapat 20 pasien rujukan ke RSUP Malalayang pada tahun 2014 karena suspect kanker payudara, 5 pasien yang tercatat positif kanker payudara, dan 2 pasien kanker payudara telah meninggal. Di antara 5 pasien kanker payudara terdapat 3 pasien yang bertempat tinggal di Desa Tumpaan Baru. Salah satu pasien kanker payudara tersebut mengatakan tidak mengetahui tentang tanda dan gejala kanker payudara bahkan SADARI hingga ia merasakan payudaranya berubah dan melakukan pemeriksaan. Para wanita bahkan para ibu sering tidak melakukan SADARI karena ketidaktahuan mereka tentang deteksi dini kanker payudara, bahkan pemeriksaan payudara itu sendiri. Padahal, melakukan SADARI dapat memberikan keuntungan bagi ibu itu sendiri dan keluarganya. Seperti penelitian yang telah dilakukan oleh Wahyuni et al tentang hubungan tingkat pengetahuan dan sikap terhadap pelaksanaan SADARI pada ibu rumah tangga di Kelurahan Jati menyimpulkan bahwa terdapat kecenderungan antara tingkat pengetahuan dan sikap ibu dapat berhubungan dengan penatalaksanaan SADARI.

Tujuan dari penelitian ini adalah untuk mengetahui hubungan tingkat pengetahuan ibu terhadap kanker payudara dan perilaku pemeriksaan payudara sendiri di Desa Tumpaan Baru Kecamatan Tumpaan Kabupaten Minahasa Selatan.

\section{B. KAJIAN TEORI}

\section{Perilaku Kesehatan}

Menurut Wawan (2011), Perilaku kesehatan pada dasarnya adalah suatu respons seseorang (organisme) terhadap stimulus yang berkaitan dengan sakit dan penyakit, sistem pelayanan kesehatan, makanan, dan lingkungan. Batasan ini mempunyai dua unsur pokok, yakni respons dan stimulus atau perangsangan. Respons atau reaksi manusia, baik bersifat pasif (pengetahuan, persepsi, dan sikap) maupun bersifat aktif (tindakan yang nyata). Sedangkan stimulus atau rangsangan disini terdiri dari 4 unsur pokok, yakni sakit dan penyakit, sistem pelayanan kesehatan, 
makanan, dan lingkungan. Dengan demikian secara lebih terperinci perilaku kesehatan itu mencakup:

a. Perilaku seseorang terhadap sakit dan penyakit yaitu bagaimana manusia berespons, baik secara pasif (mengetahui, bersikap, dan mempersepsi penyakit atau rasa sakit yang ada pada dirinya dan di luar dirinya, maupun aktif (tindakan) yang dilakukan sehubungan dengan penyakit tersebut. Perilaku terhadap sakit dan penyakit ini dengan sendirinya sesuai dengan tingkattingkat pencegahan penyakit, yakni:

- Perilaku sehubungan dengan peningkatan dan pemeliharaan kesehatan

- Perilaku pencegahan penyakit

- Perilaku sehubungan dengan pencarian pengobatan

- Perilaku sehubungan dengan pemulihan kesehatan

b. Perilaku terhadap sistem pelayanan kesehatan adalah respons seseorang terhadap sistem pelayanan kesehatan baik sistem pelayanan kesehatan modern maupun tradisional.

c. Perilaku terhadap makanan (nutrition behaviour) yakni respons seseorang terhadap makanan sebagai kebutuhan vital baghi kehidupan. Perilaku ini meliputi pengetahuan, persepsi, sikap, dan praktek kita terhadap makanan serta unsur-unsur yang terkandung di dalamnya, pengelolaan makanan, dan sebagainya sehubungan dengan tubuh kita.

d. Perilaku terhadap lingkungan kesehatan yang mencakup perilaku sehubungan dengan air bersih; perilaku sehubungan dengan pembuangan air kotor; perilaku sehubungan dengan limbah, baik limbah cair maupun limbah padat; perilaku sehubungan dengan rumah yang sehat; dan perilaku sehubungan dengan pembersihan sarang nyamuk dan sebagainya.

\section{Kanker Payudara}

Kanker payudara atau disebut juga Breast Cancer/Carcinoma mammae adalah kanker pada jaringan payudara, yaitu penyakit neoplasma yang ganas yang berasal dari parenchyma, merupakan kanker paling umum yang diderita kaum wanita (Zulkoni 2011). Ca mammae adalah suatu penyakit seluler yang dapat timbul dari jaringan payudara dengan manifestasi yang mengakibatkan kegagalan untuk mengontrol proliferasi dan maturasi sel (Brunner dan Suddarth, 2005). Kanker payudara adalah tumor ganas yang menyerang jaringan payudara. Jaringan payudara tersebut terdiri dari kelenjar susu (kelenjar pembuat air susu), saluran kelenjar (saluran air susu), dan jaringan penunjang payudara. Kanker payudara menyebabkan sel dan jaringan payudara berubah bentuk menjadi abnormal dan bertambah banyak secara tidak terkendali (Mardiana 2007).

Sel-sel kanker dibentuk dari sel-sel normal dalam suatu proses rumit yang disebut transformasi yang terdiri dari 2 (dua) tahap, yaitu: fase inisialisasi dan fase promosi (Zulkoni 2011). Pada tahap inisiasi terjadi suatu perubahan dalam bahan genetic sel yang memancing sel menjadi ganas. Perubahan dalam bahan genetic sel ini disebabkan oleh suatu agen yang disebut karsinogen, yang bisa berupa bahan kimia, virus, radiasi (penyinaran) atau sinar matahari. Tidak semua sel memiliki kepekaan yang sama terhadap suatu karsinogen. Kelainan genetic dalam sel atau bahan lainnya yang disebut promotor, menyebabkan sel lebih rentan terhadap suatu karsinogen. Bahkan gangguan fisik menahun bisa membuat sel menjadi lebih peka untuk mengalami suatu keganasan. Pada tahap promosi, suatu sel yang telah mengalami inisiasi akan berubah menjadi 
ganas. Sel yang belum melewati tahap inisiasi tidak akan berpengaruh oleh promosi. Karena itu diperlukan beberapa faktor untuk terjadinya keganasan (gabungan dari sel yang peka dan suatu karsinogen). Pada tahap promosi, suatu sel yang telah mengalami inisiasi akan berubah menjadi ganas. Sel yang belum melewati tahap inisiasi tidak akan berpengaruh oleh promosi. Karena itu diperlukan beberapa faktor untuk terjadinya keganasan (gabungan dari sel yang peka dan suatu karsinogen).

Menurut Lewis et al. (2000), terdapat beberapa faktor yang diperkirakan menjadi penyebab kanker payudara, walaupun etiologi kanker payudara belum sepenuhnya ditemukan. Hereditas dan genetika dianggap memiliki peran sebagai salah satu penyebab. Regulasi hormone pada payudara behubungan dengan pertumbuhan kanker payudara, tetapi mekanisme belum sepenuhnya dimengerti. Hormon seksual dapat bertindak sebagai pembentuk tumor bila agen awal menginduksi perubahan menjadi lebih ganas. Faktor tambahan yang telah diteliti yaitu kurangnya aktivitas fisik, asupan makanan berlemak, obesitas, dan konsumsi alkohol. Faktor lingkungan seperti bahan kimia dan paparan pestisida serta radiasi merupakan salah satu penyebab. Beberapa faktor yang menyebabkan wanita memiliki resiko yang lebih tinggi terhadap kanker payudara telah diidentifikasi. Wanita memiliki resiko lebih tinggi dibandingkan pria karena 99\% kanker payudara terjadi pada wanita. Bertambahnya usia juga meningkatkan resiko pertumbuhan kanker payudara. Kejadian kanker payudara pada wanita dibawah usia 25 tahun sangat rendah dan meningkat secara bertahap hingga usia 60 tahun.

Menurut Patrick Davey (2006) manifestasi klinis kanker payudara meliputi bejolan pada payudara, keluar cairan dari payudara, peau d'orange (kulit payudara mengkerut seperti kulit jeruk), dan benjolan di aksila. Menurut Lina Mardiana (2007), penderita yang terkena kanker payudara stadium awal atau dini tidak merasakan nyeri atau sakit pada payudaranya. Namun demikian, jika payudara diraba, ada benjolan yang tumbuh di dalamnya. Besarkecilnya benjolan yang tumbuh tersebut sangat bervariasi, tergantung seberapa cepat penderita bisa mendeteksinya. Melalui mammogram, tipe kanker payudara ini dapat dikategorikan dalam 2 (dua) bagian yaitu: Kanker payudara non invasive dan kanker payudara invasive (Zulkoni 2011).

\section{Sistem TNM}

Sistem TNM dapat dilihat pada Tabel 1. Menurut Zulkoni (2011), TNM merupakan singkatan dari:

a. "T" yaitu Tumor Size (Ukuran Tumor)

a) T0 artinya tidak ditemukan tumor primer

b) T1 artinya ukuran tumor diameter $2 \mathrm{~cm}$ atau kurang

c) T2 artinya ukuran tumor diameter antara $2-5 \mathrm{~cm}$

d) T3 artinya ukuran tumor diameter lebih dari $5 \mathrm{~cm}$

e) T4 artinya ukuran tumor berapa saja, tetapi sudah ada penyebaran ke kulit atau dinding dada atau pada keduanya, dapat berupa borok, edema atau bengkak, kulit payudara kemerahan atau ada benjolan kecil di kulit luar tumor utama.

b. 'N" yaitu Node (kelenjar getah bening regional):

a) No artinya tidak terdapat metastasis pada kelenjar getah bening regional di ketiak/aksila

b) N1 artinya ada metastasis ke kelenjar getah bening aksila yang masih dapat digerakkan 
c) N2 artinya ada metastasis ke kelenjar getah bening aksila yang sulit digerakkan

d) N3 artinya ada metastasis ke kelenjar getah bening di atas tulang selangka (supraclavicular) atau pada kelenjar getah bening di mammary interna di dekat tulang sternum.

c. "M" yaitu Metastase (penyebaran jauh)

a) Mx artinya metastasis jauh belum dapat dinilai

b) M0 artinya tidak terdapat metastasis jauh

c) M1 artinya terdapat metastasis jauh

Tabel 1. Sistem TNM

\begin{tabular}{|l|c|c|c|}
\hline \multicolumn{1}{|c|}{ Stadium } & $\begin{array}{c}\text { Tumor } \\
\text { size }\end{array}$ & Nodul & Metastasis \\
\hline Stadium 0 & T0 & N0 & M0 \\
Stadium 1 & T1 & N0 & M0 \\
Stadium 2A & T0 & N1 & M0 \\
& T1 & N1 & M0 \\
& T2 & N0 & M0 \\
Stadium 2B & T2 & N1 & M0 \\
& T3 & N0 & M0 \\
Stadium 3A & T0 & N2 & M0 \\
& T1 & N2 & M0 \\
& T2 & N2 & M0 \\
& T3 & N1 & M0 \\
& T0 & N2 & M0 \\
Stadium 3B & T4 & N0 & M0 \\
& T4 & N1 & M0 \\
Stadium 3C & T4 & N2 & M0 \\
Stadium 4 & N3 & M0 \\
\hline \multicolumn{5}{|r}{} & Tiap T & Tiap N & M1 \\
\hline
\end{tabular}

Menurut Zulkoni (2011), Ada beberapa penatalaksanaan atau pengobatan kanker payudara yang penerapannya banyak tergantung pada stadium klinik penyakit, yaitu: Mastektomi (Operasi pengangkatan payudara), Radiasi (penyinaran menggunakan sinar $\mathrm{X}$ dan sinar Gamma), dan Kemoterapi (Pemberian obatobatan anti kanker dalam bentuk pil cair atau kapsul atau melalui infus).

\section{Pemeriksaan Payudara Sendiri (SADARI)}

Deteksi dini dilakukan dengan melakukan pemeriksaan payudara sendiri atau yang dikenal dengan istilah SADARI. Ini adalah pemeriksaan yang mudah dilakukan oleh setiap wanita untuk mencari benjolan atau kelainan lainnya. Dengan posisi tegak menghadap kaca dan berbaring, dilakukan pengamatan dan perabaan payudara secara sistematis (Purwoastuti 2008). Pemeriksaan payudara sendiri adalah pemeriksaan payudara yang dilakukan sendiri dengan belajar melihat dan memeriksa perubahan payudaranya sendiri setiap bulan. Dengan melakukan pemeriksaan secara teratur akan diketahui adanya benjolan atau masalah lain sejak dini walaupun masih berukuran kecil sehingga lebih efektif untuk diobati (Direktorat Penyakit Tidak Menular, 2009).

SADARI (Periksa Payudara Sendiri) merupakan usaha untuk mendapatkan kanker payudara pada stadium yang lebih dini (down staging). Diperlukan pelatihan yang baik dan evaluasi yang reguler. SADARI direkomendasikan dilakukan setiap bulan, 7 hari setelah menstruasi bersih (Manuaba 2010). Pemeriksaan payudara sendiri (SADARI) adalah pemeriksaan atau perabaan sendiri untuk menemukan timbulnya benjolan abnormal pada payudara (Otto 2005).

\section{METODE PENELITIAN}

\section{Desain Penelitian}

Penelitian ini menggunakan desain penelitian deskriptif analitik dengan menggunakan pendekatan cross-sectional. Dalam penelitian ini peneliti ingin mengetahui hubungan tingkat pengetahuan ibu terhadap deteksi dini kanker payudara dan perilaku pemeriksaan payudara sendiri di Desa Tumpaan Baru Kecamatan Tumpaan Kabupaten Minahasa Selatan. 


\section{Populasi dan Sampel}

Populasi yang diambil adalah seluruh ibu di Desa Tumpaan Baru yaitu sebanyak 65 orang. Penelitian ini menggunakan teknik pengambilan sampel purposive sampling. Berdasarkan rumus Slovin, sampel yang digunakan sebanyak 55 responden.

$$
n=\frac{N}{N\left(d^{2}\right)+1}
$$

Dimana:

$$
\begin{aligned}
& \mathrm{N}: \text { Jumlah Populasi (65) } \\
& \mathrm{n}: \text { Jumlah sampel yang dicari } \\
& \mathrm{d}: \text { nilai presisi (0.05) }
\end{aligned}
$$

Dengan kriteria inklusi:

a. Ibu yang berusia 30-55 tahun

b. Ibu yang tidak menderita kanker payudara

c. Ibu yang tinggal di Desa Tumpaan Baru

d. Ibu yang bersedia menjadi responden

Kriteria eksklusi:

a. Ibu yang tinggal diluar Desa Tumpaan Baru

b. Ibu yang telah menderita kanker payudara

c. Ibu yang menderita gangguan kesehatan seperti cacat mental, gangguan kejiwaan, serta cacat tubuh atau tidak dapat membaca.

\section{Analisa Data}

1. Analisa univariat

Analisis univariat diperlukan untuk menjelaskan atau mendeskripsikan data secara sederhana (Budiharto 2008). Analisa ini digunakan untuk melihat karakteristik distribusi frekuensi dan variable yang akan diteliti.

2. Analisa bivariat

Analisis ini diperlukan untuk menjelaskan hubungan dua variabel yaitu variabel bebas dengan variabel terikat (Budiharto 2008). Analisa ini akan melihat apakah terdapat hubungan antara tingkat pengetahuan ibu tentang kanker payudara dan perilaku pemeriksaan payudara sendiri. Dalam penelitian ini, peneliti akan menggunakan uji statistic chi square $(a=0,05)$.

\section{HASIL DAN PEMBAHASAN}

Penelitian ini dilakukan di Desa Tumpaan Baru Kecamatan Tumpaan Minahasa Selatan. Dalam penelitian ini terdapat $55 \mathrm{ibu}$ yang ikut serta menjadi responden. Hasil penelitian ini diperoleh melalui instrument penelitian yaitu kuesioner. Tingkat pengetahuan ibu tentang deteksi dini kanker payudara diukur menggunakan kuesioner dengan 18 pertanyaan dan perilaku pemeriksaan payudara sendiri hasilnya diperoleh dari kuesioner dengan 12 pernyataan. Setelah itu, data yang telah terkumpul diolah dan kemudian disajikan menjadi data deskriptif.

\section{Umur}

Tabel 2. Distribusi frekuensi berdasarkan umur responden

\begin{tabular}{ccc}
\hline Umur & Frekuensi & Persen \\
\hline 30-40 tahun & 22 & 40.0 \\
41-50 tahun & 18 & 32.7 \\
51-60 tahun & 15 & 27.3 \\
\hline Total & $\mathbf{5 5}$ & $\mathbf{1 0 0 . 0}$
\end{tabular}

Berdasarkan Tabel 2 diperoleh responden terbanyak adalah dengan kelompok umur 30-40 tahun dengan jumlah $22 \mathrm{ibu}(40 \%)$ dan responden dengan umur 51-60 tahun merupakan responden paling sedikit dengan jumlah $15 \mathrm{ibu}(27.3 \%)$.

\section{Pendidikan Terakhir}

Berdasarkan Tabel 3 diperoleh bahwa responden yang memiliki pendidikan terakhir pada tingkat pendidikan rendah 
sebanyak $20 \mathrm{ibu}$ (36.4\%) dan responden yang memiliki pendidikan terakhir pada tingkat pendidikan tinggi sebanyak $35 \mathrm{ibu}$ $(63.6 \%)$.

Tabel 3. Distribusi frekuensi berdasarkan pendidikan terakhir responden

\begin{tabular}{ccc}
\hline $\begin{array}{c}\text { Pendidikan } \\
\text { Terakhir }\end{array}$ & Frekuensi & Persen \\
\hline Pendidikan & 35 & 63.6 \\
tinggi & 20 & 36.4 \\
Pendidikan & & \\
rendah & & $\mathbf{1 0 0 . 0}$ \\
\hline Total & $\mathbf{5 5}$ & \\
\hline
\end{tabular}

\section{Tingkat Pengetahuan}

Berdasarkan Tabel 4 diperoleh bahwa responden yang memiliki tingkat pengetahuan dengan kategori baik sebanyak $51 \mathrm{ibu}(7.3 \%)$ dan responden yang memiliki tingkat pengetahuan dengan kategori kurang sebanyak 4 ibu (92.7\%).

Tabel 4. Distribusi frekuensi berdasarkan tingkat pengetahuan responden

\begin{tabular}{ccc}
\hline $\begin{array}{c}\text { Tingkat } \\
\text { Pengetahuan }\end{array}$ & Frekuensi & Persen \\
\hline Baik & 51 & 92.7 \\
Kurang & 4 & 7.4 \\
\hline Total & $\mathbf{5 5}$ & $\mathbf{1 0 0 . 0}$ \\
\hline
\end{tabular}

\section{Perilaku Pemeriksaan Payudara Sendiri}

Tabel 5. Distribusi frekuensi berdasarkan perilaku pemeriksaan payudara sendiri responden

\begin{tabular}{lll}
\hline $\begin{array}{l}\text { Perilaku } \\
\text { SADARI }\end{array}$ & Frekuensi & Persen \\
\hline Melakukan & 41 & \\
Tidak & 14 & 25.5 \\
Melakukan & & \\
\hline Total & $\mathbf{5 5}$ & $\mathbf{1 0 0 . 0}$ \\
\hline
\end{tabular}

Berdasarkan Tabel 5 diperoleh bahwa responden yang melakukan pemeriksaan payudara sendiri sebanyak 41 ibu $(74.5 \%)$ dan responden yang tidak melakukan pemeriksaan payudara sendiri sebanyak 14 ibu $(25.5 \%)$.

\section{Hubungan Tingkat Pengetahuan Deteksi Dini Kanker Payudara dan Perilaku SADARI}

Berdasarkan Tabel 6 dapat dilihat bahwa responden dengan tingkat pengetahuan baik yang tidak melakukan SADARI sebanyak $11 \mathrm{ibu}$ dan yang melakukan SADARI sebanyak 40 ibu. Sedangkan responden dengan tingkat pengetahuan kurang yang melakukan SADARI sebanyak 3 ibu dan yang tidak melakukan SADARI hanya sebanyak $1 \mathrm{ibu}$. Serta berdasarkan uji chi-square di atas diperoleh bahwa nilai $p$ (0.047). Hal ini menunjukkan bahwa tingkat pengetahuan memiliki hubungan yang signifikan terhadap perilaku pemeriksaan payudara sendiri karena nilai $p$ lebih kecil dibandingkan nilai $a$ yaitu nilai $p(0.047)<$ $a$ (0.05). Tabel 6 juga menunjukkan nilai odds ratio sebesar 10.909, hal ini berarti responden dengan tingkat pengetahuan kurang memiliki resiko sepuluh kali tidak melakukan SADARI dibandingkan responden dengan tingkat pengetahuan baik.

Tabel 6. Hubungan tingkat pengetahuan ibu terhadap deteksi dini kanker payudara dan perilaku pemeriksaan payudara sendiri

\begin{tabular}{|c|c|c|c|c|c|c|c|}
\hline & & \multicolumn{2}{|c|}{ Perilaku SADARI } & \multirow[b]{2}{*}{ Total } & \multirow{2}{*}{$\begin{array}{c}\text { Chi- } \\
\text { square }\end{array}$} & \multirow[b]{2}{*}{$\begin{array}{c}\mathbf{p} \\
\text { value }\end{array}$} & \multirow[t]{2}{*}{ OR } \\
\hline & & $\begin{array}{c}\text { Tidak } \\
\text { Melakukan }\end{array}$ & Melakukan & & & & \\
\hline Tingkat & Baik & 11 & 40 & 51 & \multirow{2}{*}{5.581} & \multirow{2}{*}{0.047} & \multirow{2}{*}{10.909} \\
\hline Pengetahuan & Kurang & 3 & 1 & 4 & & & \\
\hline Tota & & 14 & 41 & 55 & & & \\
\hline
\end{tabular}

\section{Tingkat Pengetahuan Ibu terhadap Deteksi Dini Kanker Payudara}

Tabel 4 menunjukkan bahwa jumlah responden yang memiliki tingkat 
pengetahuan dengan kategori baik lebih banyak dibandingkan responden yang memiliki tingkat pengetahuan dengan kategori kurang. Pengetahuan responden yang menunjukkan bahwa tingkat pengetahuan baik memiliki jumlah terbanyak berbanding lurus dengan jumlah responden yang memiliki pendidikan terakhir pada tingkat SMA dan S1. Pengetahuan seseorang dipengaruhi oleh pendidikan yang dijalani oleh seseorang tersebut. Pendidikan formal merupakan salah satu usaha yang diharapkan dapat menambah pengetahuan seseorang. Semakin tinggi tingkat pendidikan diharapkan semakin luas pula pengetahuannya, tetapi bukan berarti seseorang dengan tingkat pendidikan yang rendah mutlak berpengetahuan rendah pula. Pengetahuan seseorang juga dapat dipengaruhi oleh faktor eksternal seperti informasi yang diperoleh diluar bangku sekolah, misalnya faktor lingkungan.

Faktor eksternal tersebut dapat mencakup acara iklan layanan masyarakat maupun acara komersil tentang kesehatan yang menjadi perhatian masyarakat pada beberapa televisi swasta di Indonesia. Seperti penelitian yang dilakukan oleh Putri pada tahun 2012 bahwa iklan masyarakat tentang $\mathrm{KB}$ di televisi mempengaruhi perilaku KB pada wanita atau pria usia subur. Begitu pula dalam penelitian ini, beberapa responden mengatakan pengetahuan mereka dipengaruhi oleh siaran komersil tentang kesehatan yang ada di televisi swasta Indonesia yang juga sering membahas tentang kanker sehingga walaupun tingkat pendidikan SMA tetapi pengetahuan mereka tentang deteksi dini kanker payudara cukup tinggi.

Dalam penelitian ini pada Tabel 2 menunjukkan bahwa responden dengan kelompok umur 30-40 tahun merupakan responden terbanyak (40\%). Data menunjukkan bahwa selain tingkat pendidikan, tingkat pengetahuan seseorang dapat dipengaruhi oleh usia.

\section{Perilaku SADARI}

Tabel 5 menunjukkan bahwa SADARI menunjukkan jumlah responden yang melakukan pemeriksaan payudara sendiri (SADARI) lebih besar dibandingkan jumlah responden yang tidak melakukan SADARI. Hal ini dapat diketahui karena jumlah responden yang melakukan SADARI sebanyak 41 responden dan yang tidak melakukan hanya 14 responden. Pada Tabel 6 dapat dilihat bahwa jumlah responden yang memiliki tingkat pengetahuan dalam kategori baik dan juga melakukan SADARI lebih banyak dibandingkan responden dengan tingkat pengetahuan dalam kategori baik yang tidak melakukan SADARI. Hal tersebut dapat dibuktikan dengan jumlah responden dengan tingkat pengetahuan baik dan melakukan SADARI sebanyak 40 ibu dibandingkan jumlah responden yang tingkat pengetahuannya berada pada kategori baik dan tidak melakukan SADARI hanya sebanyak 11 responden. Tabel 6 juga menunjukkan bahwa jumlah responden yang memiliki tingkat pengetahuan kurang dan melakukan SADARI lebih sedikit dibandingkan jumlah responden yang memiliki tingkat pengetahuan kurang dan tidak melakukan SADARI. Ini ditunjukkan oleh jumlah responden dengan tingkat pengetahuan kurang dan melakukan SADARI hanya 1 responden, sedangkan jumlah responden yang memiliki tingkat pengetahuan kurang dan tidak melakukan SADARI sebanyak 3 responden. Perilaku dipengaruhi oleh faktor endogen dan eksogen, dimana faktor pendidikan merupakan salah satu yang termasuk dalam faktor eksogen. Hal ini berkaitan dengan hasil analisa pendidikan responden. Responden yang memiliki pendidikan terakhir pada tingkat pendidikan tinggi 
memiliki jumlah lebih banyak dibandingkan pada tingkat pendidikan rendah. Sama halnya menurut Wawan (2011), bahwa perilaku seseorang juga dapat dipengaruhi oleh pengetahuan yang dimiliki seseorang tersebut. Pendapat ini sesuai dengan jumlah responden yang memiliki tingkat pengetahuan baik lebih banyak dibandingkan responden yang memiliki tingkat pengetahuan kurang. Sehingga responden yang memiliki tingkat pengetahuan baik sebagian besar melakukan SADARI jumlahnya lebih banyak dibandingkan responden yang memiliki tingkat pengetahuan kurang.

\section{Hubungan Tingkat Pengetahuan Ibu Terhadap Deteksi Dini Kanker Payudara dan Perilaku SADARI}

Hubungan tingkat pengetahuan ibu terhadap deteksi dini kanker payudara dan perilaku SADARI dapat dilihat pada Tabel 6 . Tabel 6 memperlihatkan nilai $p(0.047)$. Nilai $p$ tersebut menunjukkan bahwa antara tingkat pengetahuan ibu terhadap deteksi dini kanker payudara memiliki hubungan yang signifikan terhadap perilaku SADARI. Hal tersebut dikarenakan nilai $p$ lebih kecil dibandingkan nilai $a(0.047<0.05)$. Pada tabel 6 dapat diperoleh Odds Ratio (OR) yang menunjukkan responden yang memiliki tingkat pengetahuan kurang sepuluh kali lebih beresiko tidak melakukan perilaku SADARI dibandingkan responden yang memiliki tingkat pengetahuan tinggi. Analisa jumlah responden yang memiliki tingkat pengetahuan baik maupun kurang yang melakukan SADARI dan yang tidak melakukan SADARI serta hubungan antara tingkat pengetahuan dan perilaku SADARI dapat mencerminkan bahwa SADARI responden lakukan seiring dengan peningkatan pengetahuan tentang kanker payudara dan deteksi dini kanker payudara yang dimiliki oleh responden.
Responden yang memiliki tingkat pengetahuan baik memiliki tingkat kewaspadaan lebih tinggi. Hal ini dikarenakan responden tersebut lebih banyak mengetahui tentang faktor resiko kanker payudara, tanda dan gejalanya, serta cara mendeteksi dini kanker payudara. Hal ini menyebabkan responden juga melakukan SADARI dalam kehidupan sehari-hari karena mereka memiliki kekhawatiran bila terlambat mengetahui gejala kanker yang terjadi pada tubuh mereka dan akhirnya kanker tersebut akan sulit untuk diobati. Seperti hasil penelitian yang dilakukan oleh Pengpid et al. (2014) dimana intensitas responden melakukan SADARI meningkat bersama dengan anggapan mereka bahwa SADARI itu penting. Analisa tentang responden yang memiliki tingkat pengetahuan baik tetapi tidak melakukan SADARI yang berjumlah 11 orang, penulis peroleh saat melakukan observasi serta melalui wawancara bahwa responden memiliki kecemasan ketika mendapatkan benjolan saat mereka melakukan SADARI. Hal tersebut mengakibatkan responden tidak melakukan SADARI walaupun mereka memiliki tingkat pengetahuan yang baik tentang kanker payudara maupun deteksi dini kanker payudara. Hal ini didukung oleh penelitian yang dilakukan oleh Amier et al. (2014) yang menyimpulkan bahwa ada hubungan yang bermakna antara pengetahuan, kecemasan, ketakutan dengan pemeriksaan payudara sendiri pada siswi PGRI Minasatene Kab. Pangkep. Berbeda pada responden dengan tingkat pengetahuan kurang tetapi melakukan SADARI walaupun hanya berjumlah 1 orang, penulis dapat menganalisis berdasarkan hasil wawancara dan observasi bahwa selain pendidikan dan usia, lingkungan juga mempengaruhi perilaku. Di Desa Tumpaan Baru terdapat 2 ibu yang telah meninggal yang disebabkan oleh kanker payudara. Oleh karena itu, walaupun responden 
tersebut tidak memiliki pengetahuan yang baik tentang kanker payudara dan deteksi dini kanker payudara, responden tersebut memiliki kewaspadaan yang membuat mereka untuk melakukan SADARI. Responden dengan tingkat pengetahuan kurang perilaku mereka lebih dipengaruhi oleh lingkungan dibandingkan pengetahuan yang mereka miliki.

Hasil penelitian ini bertolak belakang dengan penelitian terkait yang telah dilakukan oleh Sugiharto (2014) dan Nugrahini et al. (2012). Sugiharto (2014), pada penelitiannya yang berjudul hubungan antara pengetahuan kanker payudara dengan perilaku SADARI yang dilakukannya pada mahasiswi Fakultas Keguruan dan Ilmu Pendidikan menghasilkan bahwa tidak ada hubungan antara tingkat pengetahuan kanker payudara dan perilaku SADARI. Sama halnya dengan penelitian yang telah dilakukan oleh Nugrahini et al. (2012), yang berjudul hubungan tingkat pengetahuan dengan perilaku SADARI pada mahasiswa Fakultas Ilmu Keperawatan Universitas Padjajaran yang menjelaskan bahwa perilaku SADARI mahasiswa tidak berhubungan dengan pengetahuan mereka.

Penelitian ini memiliki hasil yang sama seperti penelitian yang dilakukan oleh Wahyuni et al. (2015), pada penelitiannya yang berjudul Hubungan Tingkat Pengetahuan Dan Sikap Terhadap Pelaksanaan SADARI Pada Ibu Rumah Tangga Di Kelurahan Jati yang menunjukkan bahwa terdapat kecenderungan tingkat pengetahuan dan sikap dapat berhubungan dengan penatalaksanaan SADARI. Begitu pula dengan penelitian yang telah dilakukan oleh Ekanita et al. (2013), yang berjudul Hubungan Antara Pengetahuan Dan Sikap WUS Terhadap Perilaku Pemeriksaan Payudara Sendiri (SADARI) yang menyimpulkan bahwa ada hubungan pengetahuan dan sikap WUS terhadap perilaku SADARI.

\section{E. KESIMPULAN}

Berdasarkan hasil yang diperoleh maka dapat disimpulkan:

1. Sebagian besar responden memiliki tingkat pengetahuan baik terhadap deteksi dini kanker payudara.

2. Sebagian besar responden melakukan pemeriksaan payudara sendiri.

3. Ada hubungan yang bermakna antara tingkat pengetahuan ibu terhadap deteksi dini kanker payudara dan perilaku pemeriksaan payudara sendiri.

Adapun yang menjadi saran dalam penelitian selanjutnya adalah sebaiknya instrument penelitian tentang perilaku pemeriksaan payudara sendiri bisa lebih spesifik serta bila memungkinkan dapat memberikan pengajaran tentang cara melakukan SADARI pada responden atau masyarakat yang memiliki tingkat pengetahuan kurang dan tidak mengetahui cara melakukan SADARI.

\section{F. DAFTAR PUSTAKA}

American Cancer Society. 2012. Breast Cancer Facts \& Figures 2011-2012. Atlanta: American Cancer Society Inc.

Amier, H., Djawarut, H. 2014. Faktorfaktor yang Berhubungan dengan Pemeriksaan Payudara Sendiri (SADARI) pada Siswi SMK PGRI Kab. Pangkep. Jurnal Ilmiah Kesehatan Diagnosis. 5(2) ISSN:2302-1721.

Budiharto. 2008. Metodologi Penelitian Kesehatan Dengan Contoh Bidang Ilmu Kesehatan Gigi. Jakarta: EGC. 
Brunner., Suddarth. 2005. Keperawatan Medikal Bedah Edisi 8. Jakarta: EGC.

Dovey, P. 2006. At a Glance Medicine. Jakarta: Erlangga.

Ekanita, P., Khosidah, A. 2013. Hubungan Antara Pengetahuan Dan Sikap Wus Terhadap Perilaku Pemeriksaan Payudara Sendiri (SADARI). Jurnal Ilmiah Kebidanan. 4(1):167-177.

Gunarsa, SD., Gunarsa, SDY. 2008. Psikologi Praktis: Anak, Remaja dan Keluarga. Jakarta: Gunung Mulia.

Lestari, S. 2012. Psikologi Keluarga Penanaman Nilai dan Penanganan Konflik dalam Keluarga. Jakarta: Kencana Prenada Media Group.

Lewis, S., Heitkemper, M., Dirksen, S. 2000. Medical-Surgical Nursing Assessment and Management of Clinical Problems Fifth Edition. USA: Mosby Inc.

Manuaba, I. 2010. Ilmu Kebidanan, penyakit Kandungan dan KB untuk Pendidikan Bidan Edisi 2. Jakarta: EGC.

Mardiana, L. 2007. Kanker pada Wanita Pencegahan dan Pengobatan dengan Tanaman Obat. Jakarta: Penebar Swadaya.

Nugrahini, DS., Anna, A., Emaliyawati, E. 2012. Hubungan Tingkat Pengetahuan Dengan Perilaku SADARI Pada Mahasiswa Fakultas Ilmu Keperawatan Universitas Padjajaran. Jurnal Fakultas Ilmu Keperawatan Universitas Padjajaran. 1(1).

Otto, S. 2005. Buku Saku Keperawatan Onkologi. Jakarta: EGC.
Pengpid, S., Peltzer, K. 2014. Knowledge, Attitude and Practice of Breast Selfexamination Among Female University Students from 24 Low, Middle Income and Emerging Economy Countries. Asian Pacific Journal of Cancer Prevention.

Putri, PKD. 2012. Pengaruh Tingkat Pendidikan, Pengetahuan, Sikap dan Terpaan Iklan Layanan Masyarakat KB Versi Shireen Sungkar dan Teuku Wisnu di TV terhadap Perilaku KB pada Wanita atau Pria dalam Usia Subur. Jurnal Interaksi.

Purwoastuti, E. 2008. Kanker Payudara Pencegaham Deteksi Dini. Yogyakarta: Kanisius.

Sugiharto, S. 2014. Hubungan antara pengetahuan kanker payudara dengan perilaku SADARI. Thesis Faculty Of Nursing Widya Mandala Catholic University Surabaya.

Wahyuni, D., Edison., Harahap, WA. 2015. Hubungan Tingkat Pengetahuan Dan Sikap Terhadap Pelaksanaan SADARI Pada Ibu Rumah Tangga Di Kelurahan Jati.

Wawan, A., Dewi, M. 2011. Teori dan Pengukuran Pengetahuan, Sikap, dan Perilaku Manusia Dilengkapi Dengan Contoh Kuesioner. Yogyakarta: Nuha Medika.

Global Health Observatory (GHO). 2015. Cancer Mortality and Morbidity Situation and Trends.

World Health Organization. 2014. Cancer Country Profiles-Indonesia.

Zulkoni, A. 2011. Parasitologi. Yogjakarta: Nuha Medika. 